\title{
FALLING INTO MARXIST SOCIOLOGY: CHOOSING TO STAY
}

\author{
Erik Olin Wright \\ University of Wisconsin
}

Mid-American Review of Sociology, 1991, Vol XV, No. 2:1-14

In 1968, as a senior at Harvard, I made a film called "the Chess Gamen as part of a course I took in animation. The basic story of the film was simple:

Using "solid animation" techniques (i.e. moving a piece slightly and then shooting a frame of film), the film revolves around a chess game. It is a game in which many pawns are lost (from a chess point of view it is a terrible game). When a piece is taken, it falls over and is kicked off the board. The pawns gradually pile up next to the board. Eventually you see them talking to each other, the two sides mixed together. After a while, in a burst of action, they attack the aristocratic pieces playing the game. The soundtrack changes from Baroque harpsichord music to Stravinsky's "The Rite of Spring". Before long, the clite is defeated and pushed from the board. The pawns then dance a Virginia Reel folk dance, light and dark pieces intermingled. The screen fades out. But is the story over? No. The picture comes back on and you see the pieces marching back onto the board. They line up to play a new chess game, only this time the pawns are on the back rows and the old aristocratic pieces on the front rows. The pawns now move like knights, queens, bishops; the elite of the ancien regime is reduced to the status of pawns. And the game begins again.

I made that film at a momentous time in the history of the left, in the Western world for sure. The following autumn I showed it at an international student center in Paris. People were still living in the aftermath of the events of May of that year. After the film was shown, a North Vietnamese student stood up and denounced it on the ground that it represented the complete futility of the attempt at revolutionary change. In his view, the message of the film was la plus a change, la plus c'est le mine chose (the more things change, the more they stay the same). I replied that this was a misunderstanding of the message of the film. The point of the film is that you can't dance a revolutionary square dance on a chess board. The mistake of the pawns in this fable was to imagine that by simply eliminating the ruling class from the board they could reconstruct the new society. The board was supposed to represent the social structure that produces the games that we play, not simply a "natural" or neutral background for the action. Thus, what the pawns needed to do was to remove the board itself from the field, not simply the previous players. In failing to do so, in the end, they recreated the same old game but 
with a reversal of the traditional roles. You can't dance a square dance for long on a chess board.

I must admit that this articulate account of the film's message comes from later reflections on my own intuitions that were at work in making the film. Still, I think the film does show something about where my own thinking was at a time before I would have identified my own intellectual work as Marxist. It wasn't really until several years later, during the early seventies when I was a graduate student, that I first began to explicitly identify my work in this way. Nevertheless, I had all the basic intuitions in place, at least it seems to me, prior to the recognition that, indeed, those intuitions were essentially Marxist intuitions. This is part of what I had in mind when I adopted the title for this talk, "Falling into Marxism, Choosing to Stay". The allusion is, of course, somewhat of a romantic one: you fall in love, but you choose to get married. (And increasingly you choose to stay married given the ease with which one can get divorced.)

In my own biography, I think that what I learned in my first years in graduate school was that I was already in fact "Marxist" in my own views about the world. This was more of a discovery than a choice. Given this discovery, however, I have faced a series of more or less conscious choices at various junctures in my career. It is on the nature of these choices that I would like to focus in this discussion.

Reflecting upon the interplay of choice and context is basic bread and butter sociology: intended and unintended consequences; rational calculation and normative action; choices under constraints. The particular twist I'd like to give to the notion of the dialectic between choice and constraint is found in the story of Ulysses and the Sirens -- choices you make today are sometimes consciously made with an eye to constraining your future choices. (This use of the Ulysses and the Sirens metaphor comes from Jon Elster's book, Ulysses and the Sirens, Cambridge University Press). Ulysses knew, as a form of meta rationality, that he was going to face a situation shortly in which he did not want to be able to make choices. He wanted to be tied to the mast and he instructed the sailors on the ship not to listen to his calls to be released because he knew that if he were free he would bring on his downfall. At one point in time, therefore, he had the capacity to make choices that would constrain his future choices.

A series of choices that I've made in the course of my career have this basic Ulysses and the Sirens character: in one way or another I made strategic choices with more or less understanding of how these choices would constrain the possibility of choices in the future. Choices made at five such junctures seem especially important to me: The first of these has to do with the choice to identify my work primarily as contributing to Marxism rather than simply using Marxism. The second concerns my choice to be a sociologist, rather than some other "ist". The third is the choice to become what some people describe as a multivariate Marxist: to be a Marxist sociologist who engages in grandiose, perhaps overblown, quantitative research. The fourth choice is the choice of what academic department to be in. This choice was acutely posed to me three years ago after spending a year as a visiting professor at Berkeley. I had been offered a position at Berkeley and I had to decide whether I wanted to return to Wisconsin. Returning to Madison was unquestionably a choice. Finally, and the issue that I will spend more time on, is the choice to stay a Marxist in this world of post-Marxism when many of my intellectual comrades have decided for various good, and perhaps not so good, reasons to recast their intellectual agenda as being, friendly to, but outside of the Marxist tradition.

To set the stage for this reflection on choice and constraint, let me tell you a little about the trajectory of my life that brought me into the arena of these choices. (My mother, who will be speaking after me, might have more to say about these earlier choices when I was still young).

I knew that I wanted to be a professor by about age ten. Both of my parents are academics; both of my siblings are academics; both of their spouses are academics. The joke in the family is that the only social mobility is interdepartmental. If you go one generation further back, that's no longer the case; but it was just obvious to me that being a professor was the thing to be. I never experienced that as a real choice. Literally it never was an experience to decide to become a professor. As long as I can remember ever thinking about what I wanted to do with my life, that's what I wanted to do.

In a funny way being an undergraduate at Harvard was also not really a choice in the sense of a decision coming after a careful weighing of alternatives and thinking through consequences. I was a high school student in Lawrence, Kansas. By the time I graduated from high school I had accumulated a bunch of KU credits. All my friends were going to KU. It just seemed like the thing to do, to go to KU. A friend of the family, Karl Hieder (his mother, Grace Hieder is with us in the audience), gave me as a Christmas present in my senior year in high school an application form to Harvard. He was a graduate student at Harvard in anthropology at the time. I filled it out and sent it in. Harvard was the only place to which I applied, not out of inflated seif-confidence but because it was the only application I got as a Christmas present. When I eventually got accepted (initially I was on the waiting list), the choice was thus between $\mathrm{KU}$ and Harvard. I suppose this was a choice since I could have decided to stay at KU. However, it just seemed so obvious; there was no angst, no weighing of alternatives, no thinking about the pros and cons. Thus going to Harvard, like becoming a professor, in a way just happened, rather than being chosen.

I could list a number of other things of this character: I got a scholarship to study at Oxford for two years after I finished at Harvard. Well, for a young intellectual who loved to study and read and liked new settings, it just seemed ridiculous not to go to Oxford. It was, just again, not a real choice. I didn't weigh the consequences. It was just the obvious thing for me to do.

My career, however, does not entirely consist of a meandering walk through nonchoices of obvious alternatives, and what I would like to focus on now is a series of junctures which did have more of the character of choices 
in which there was real deliberation and thought about the implications of different options.

\section{Becoming a Marxist: Accountability and Eclecticism}

When I began graduate school in Berkeley in 1971 I was already quite radicalized intellectually and politically. The previous year I had spent as a student at a Unitarian seminary in Berkeley, the Thomas Starr King School of the Ministry. I enrolled in the seminary not out of a deep and abiding commitment to the ministry as a possible vocation -- that never occurred to me as something I would actually do -- but because it was the only way I could think of at the time to keep out of the Army in the context of the Vietnam War. The enrollments at seminaries, especially in Unitarian seminaries, increased dramatically in the late sixties. During the year I spent at the Unitarian seminary in Berkeley, I was a student chaplain at San Quentin prison and became actively involved in something called the Prison Law Project. This was an activist organization, particularly (but not exclusively) linking radical black prisoners with leftwing lawyers, devoted to challenging prison conditions through litigation and other forms of activism. In the context of my work with the Prison Law Project and my role in the prison, I decided with my friends in the Project to write a book about San Quentin which eventually became published as the Politics of Punishment, about half of which was written by me, and the rest by prisoners and others connected with the Prison Law Project.

The Politics of Punishment was the first context in which I had to deploy systematically my emerging theoretical perspective in an academic context of writing a sustained analysis. I wrote that book during my first year of graduate school in sociology at Berkeley. It was really in that context that it became clear to me that, not only were my ideas compatible with Marxism, but indeed, what I was, in terms of my own intellectual commitments, was Marxist. There was a discovery, in effect, that there existed an on-going intellectual tradition which accorded very closely with my views. I came to that understanding not through a deep study of Marx. I hadn't at that point read Capital, for example. I had had the typical kind of Harvard undergraduate exposure to certain classic bits of Marxism and I did a little more of that when I was studying history at Oxford. But basically the discovery that my ideas could properly be labeled "Marxist" was not the result of insights informed by a careful reading of the classics, but rather of an exposure to the central themes and current debates of Marxism as an on-going intellectual tradition. I thus came to Marxism more through the contemporary substantive arguments of class analysis and political economy rather than through classical texts.

While I discovered that my ideas fell firmly within the Marxist tradition, there was still a basic choice to be made. This is the first crucial branch point that I want to identify. Among radical intellectuals there is an important distinction between defining one's work as drawing from the Marxist tradition on the one hand, or seeing one's work as contributing to the reconstruction of Marxism on the other. Many scholars acknowledge that their work is in important ways inspired by Marxism without taking the additional step of seeing it as contributing to Marxism. One can, if you will, do Marxism without being a Marxist.

Most of what I have written, if you strip away certain rhetorical parts which make a big deal about how this is contributing to Marxism, could just as well have been written in the softer spirit of Marxist inspiration. I could have framed my arguments by saying something like "the Marxist tradition is a rich and interesting source of ideas. We can learn a lot from it. Let's see where we can go by taking these traditional notions of class and massaging them, changing them, combining them with other elements in various ways." I could have cast my class analysis this way without any commitment to Marxism per se as a tradition worth reconstructing.

Many sociologists in the late 1960s and early 1970s, radical intellectuals of my generation, made the opposite choice. Take as an example Theda Skocpol's work, especially her first book, States and Social Revolutions. This book could have been written as a Marxist work with no change in any substantive thesis in it. It could have been written as a book that was amending and reconstructing certain weaknesses in the Marxist tradition in order to rebuild and strengthen that tradition. Instead she chose, for reasons that she would have to explain in her own set of intellectual and personal coordinates, to treat the book as a dialogue with the Marxist tradition but firmly, rhetorically, outside it. I made the opposite choice. The question is, why did I do this, what was my thinking behind it?

Let me give you a vignette which I think helps to reveal what's at issue here. In 1986 I gave a talk in Warsaw called "Rethinking Once Again, Alas, the Marxist Concept of Class" or some pretentious title like that. In the talk I discussed such things as contradictory class locations, exploitation and post-capitalistic society, the role of the control over different kinds of assets for constructing new kinds of exploitation and so on. Afterwards, the first question was: "Professor Wright, I find your ideas very interesting and very compelling. I think there is a lot to be discussed about them, but why do you call this Marxist? Why deflect attention from what you are really talking about by saying that this has anything to do with Marxism?" What is at issue here is a dramatic difference in the contexts for pursuing radical intellectual work. In the Polish context to declare that this was a reconstruction of Marxism meant something utterly different from what the same statement means, the same words mean, when they are declared in the context of American sociology. In Poland, to reconstruct Marxism is to salvage the ideology of state repression. In the United States, to embed onc's work in a rhetoric of reconstructing Marxism means something entirely different.

Thus I think the first motivation behind the declaration of my work as contributing to Marxism centers around a point in the sociology of knowledge. What does it mean to define one's work as integral to an oppositional current within an established set of institutions? This is very close to what sociologists talk about when they talk about "reference groups," although I think this has 
more consequences than just the people to whom one feels connected and to whom one feels responsible. What really was at stake to me was the nature of the constituency or audience to whom I wanted to feel accountable. Whose criticisms did I want to worry about, and whose did I want to simply be able to dismiss?

This issue of active constituency or reference group is reflected in the gut reaction I get when a paper of mine is rejected by the American Sociological Review, which happens quite regularly, in contrast to the way I feel when I get a paper rejected by New Left Review. which happens less regularly, but does happen. [I recently had a paper called "Emancipation and Explanation of Marxism and Feminism" rejected by New Left Review, although with an encouragement to resubmit, which I subsequently did]. When I get a paper rejected by $A S R$ I am basically pissed off. I'm annoyed and frustrated by the amount of additional work, usually of a boring technical character that will have no consequences for any substance of knowledge, that I'm forced to do to deal with the objections that have been raised. When I have a paper rejected by New Left Review I get worried, it makes me very anxious. I need a bigger space of time to even think through the criticisms. In the case of my recent paper on Marxism and Feminism I got ten single-spaced pages of criticisms back from the board of NLR. I couldn't even read them until I had a period of a couple of days uncluttered by other work; it was too anxietyprovoking for me to even contend with the ideas and issues they were raising. That never happens when I get rejected from $A S R$. I just get mad about it and go about my business.

These psychological issues are an important part of what is at stake in making the choice to see my work as embedded in the Marxist tradition, as contributing to the reconstruction of that tradition rather than simply drawing on it. Defining my work this way establishes whom I am accountable to, whose opinions are going to matter. The issue of reference group, however, is not just psychological, since reference groups are also social networks that dispose of. real resources and impose real pressures of various kinds. Choosing a reference group, then, has the effect of creating a set of constraints which one faces in the future.

In the decision to describe my work as contributing to Marxism, then, there is a kind of Ulysses and the Siren story at work. It is an attempt, however imperfect, at blocking certain pressures of co-optation which one experiences once one enters a profession. It is an attempt to make life more difficult for oneself. The same holds true for feminist sociologists today. Some feminists say that their work is contributing to feminism as such. Rather than just contributing to sociology inspired by feminism, they see their work as contributing to building Feminist Theory. Such declarations make life more difficult, since you could say most of the same things without framing your agenda in this more provocative manner. Making one's life more difficult in this way, however, is not a sign of masochism; it is a strategy which makes it harder to inadvertently slide into a theoretical and intellectual practice which is overwhelmed by it's acceptability. The pressures for mild, nonconfrontation- al, acceptable scholarship are enormous, and situating one's work firmly in a radical oppositional current is one way of partially neutralizing those pressures.

There is another side to the choice to contribute to building Marxism as an intellectual tradition rather than simply using it, which entered my own decisions and which has become increasingly important in my subsequent on-going decision to stay in Marxism rather than to become, as is fashionable these days, post-Marxist. This second aspect of the choice raises philosophy of science rather than sociology of knowledge issues. What is the best way to contribute to the enhancement of our knowledge of social life? Is the most productive strategy to work within what one considers the best available paradigm, or is it better to take a more eclectic approach, avoiding any strong commitment to a single perspective but instead picking and choosing from different traditions as is appropriate for different particular questions one might ask? In a somewhat stylized way we can contrast two stances towards these issues: a stance which places great value on ambitious programs for theoretical coherence and integration in the form of a sustained paradigm, and a stance, which is sometimes referred to as a more empiricist approach, which argues that what we want to do is deeply and intensively describe the world while eclectically drawing from different sorts of ideas as we see fit for different problems.

My views on this contrast of intellectual practices are not the conventional ones for someone who is committed to a paradigmatic view of knowledge in his own work. Most people who are committed to some kind of effort at building strong paradigms are anti-eclectic: eclecticism is viewed as the enemy of paradigm building. I believe, to the contrary, that there is a symbiotic relationship between paradigm-mongers and carefree eclectics. The optimal intellectual terrain for radical theory -- or for any sociological knowledge for that matter -- is a mixture of people who are committed eclectics and people who are committed paradigmists. If I could snap my fingers and make every radical intellectual a committed Marxist, I wouldn't do it. I think it would be bad for Marxism and certainly bad for the left. If I could snap my fingers and make everybody a committed eclectic, if that's not an oxymoron, I would also not do it. Eclecticism is in a certain sense parasitic on committed paradigms. To be an effective eclectic, you've got to have some other scholars around who are worrying obsessively about how to rebuild paradigms and maintain the maximum coherence possible within them. But if that's what everyone did, it would be a constraint on the possibility of effectively reconstructing paradigms because the puzzles and worries and anomalies that a reconstructive project faces often come from the insights generated by the eclectics.

The environment of intellectual work that I see as optimal, and which I try to achieve to the extent possible in the intellectual circles within which I work, thus values an intellectual pluralism in which no one is holier-than-thou about meta-theoretical principles. Dialogue between the doubts of the eclectics and the commitments of the paradigmists strengthen both. These issues hold for contemporary feminism as well as Marxism. In the feminist tradition 
radical feminism is crucial for healthy feminism, even though I think radical feminism is the least plausible version of feminism. Still, it would be a shame for the feminist tradition if radical feminists were somehow persuaded to abandon the most radical and extreme forms of feminism. Similarly for the socialist tradition of intellectual work, it is important to have a body of scholarship and intellectual work which remains committed to rebuilding rather than simply drawing from the Marxist tradition.

\section{Becoming a Sociologist: Nondisciplines and Intellectual Pluralism}

Let me say a couple of words about the intermediary choices and then I'll turn to the last issue of staying a Marxist. The second choice was the fateful decision to become a sociologist. I still consider myself being in sociology rather than of sociology. I see sociology as a platform on which to do my work rather than a discipline to which I feel any great commitment as such (although I have to admit that over time my sense of loyalty to the field has grown a bit). As an undergraduate I majored in an interdisciplinary social science program (social studies), after which I studied history for two years at Oxford. I see myself as a social scientist and social theorist rather than a capital S Sociologist. Why, then, did I chose Sociology as an academic home?

Of all the available social sciences, sociology seemed to me to be the least disciplinary; it had the fuzziest boundaries. But even more significantly, Sociology has valued it's own marginal traditions in a way that other social sciences don't. In economics, Marx is described as a third-rate post-Ricardian. (That's a famous quote by Paul Samuleson, the Nobel prize winner economist). Even anti-Marxist sociologists recognize the importance of Marx as one of the intellectual founders of what has become sociology. All graduate courses in theory contain at least some reading of Marx. There are economic departments in which the name Marx would never be mentioned. The only social science discipline that might have served as well as sociology was political science, and I suppose if I had been at some other University I might have become a political scientist. But at Berkeley I felt that sociology was a more congenial place in which to be a radical, and in general I now think political science tènds to be someiwhat less hospitable tô radicalism because of the tight relationship between political science and the state. Political science is a breeding place for government advisers and policy analysts, and that aspect of political science as a discipline would be a constraint that $I$ did not want to choose. So, I chose sociology.

\section{Becoming a Multivariate Marxist: Legitinating Marxism and Careerism}

Very quickly in graduate school, even in a place like Berkeley, it becomes clear where the intellectual core of the discipline lies. Having decided to be a sociologist and having as a mission the reconstruction of Marxism as a social science, I saw a crucial task of my work to try to increase the credibility of Marxism within the academy, and I felt that quantitative research would accomplish this. As a wrote in 1987, reflecting on my early theoretical ambitions:
I originally had visions of glorious paradigm battles, with lances drawn and the valiant Marxist knight unseating the bourgeois rival in a dramatic quantitative joust. What is more, the fantasy saw the vanquished admitting defeat and changing horses as a result.

My decision to launch a series of projects at the core of which were sophisticated statistical techniques was not driven by any epistemological conviction that these techniques generated deeper or more reliable knowledge. Indeed, on that score I have found nearly always that I learn more from good qualitative and historical research than from research by quanto-maniacs. But I felt that at that point in the history of Marxism in Sociology (the mid-1970s), establishing the credibility of Marxism within a quantitative methodology had the greatest chance of making a difference in the intellectual space Marxists could occupy within the academy.

To be honest, there was also, from the start, a darker side to the appeal of quantitative research. Just as it became clear where the intellectual core of sociology was going in the 1970s, it was also clear what kinds of research were likely to generate grants and acclaim. All academic disciplines as institutions contain a system of rewards and sanctions that channels work in particular directions, and there was clearly more resources to be had through quantitative research. I was very ambitious as a young scholar -- ambitious in my search for what I considered to be the "truth," but also ambitious for status, recognition, influence, world travel. Embarking on a line of research anchored in conventional survey research thus offered tangible rewards.

I cannot reconstruct exactly what the balance of these motives were in the mid-1970s when I did my dissertation research, a quantitative study of class structure and income determination, or the late 1970s when I began my still on-going comparative project on class structure and class consciousness. But whatever the balance between grantsmanship and intellectual purpose, the choice to direct my research in this way has been enormously consequential, and not always in ways to my liking. It has resulted in a narrowing of askable questions and divergence between much of my best theoretical work and my empirical research. Originally, the idea in 1978 when I began the comparative class analysis project was to do a survey of class structure and class consciousness in the US, Italy and Sweden. This was meant to be a brush-cleaning operation: settling and clarifying a range of empirical issues before returning to the problems I cared about the most -- the state, politics, social change. It is now 13 years later. The survey has been done in 11 countries and is being done or about to be done in five to ten more, including the USSR, Taiwan, Korea, Switzerland and possibly most of the countries of Eastern Europe. Because of the scale of the enterprise, I have created a set of expectations and commitments that cannot be easily (or responsibly) abandoned, and yet the work does not always yield intellectual insights in proportion to the time and resources the project absorbs. Still, this project will yield the largest systematically comparative data set on class and its ramifications. 
4. Choosing a Department: Discipline Oriented Versus Intellectual Sociology I initially went to the University of Wisconsin without a great deal of thought and deliberation. I had some graduate school friends there and the department actively recruited me, so $I$ never really went on a national job search to explore all options. In 1987-88, however, I spent a year at the University of California in Berkeley, and by the end of the year was clearly faced with a genuine, unmistakable choice, a choice laden with "road not taken" potentials.

Here is how I would characterize the big difference between these two departments. If you think of the famous people in the Berkeley department what comes to mind are titles of books. When you think of the famous people in the Wisconsin department what comes to mind is the journals in which they publish and the topics which they pursue. Philip Selznick is TVA and the Grass Roots; Bob Hauser is "Mr. Mobility." Wisconsin is an article writing department and Berkeley is a book writing department.

This contrast between the two departments is also reflected in the nature of their graduate programs: at Wisconsin a significant number of graduate students write dissertations that are spin-offs in one way or another from large, on-going research projects. The model of education is that of an apprenticeship, and while students are expected to do original and innovative work, the core model is to do so within the context of some professor's research shop. At Berkeley, it is quite rare for students to play this apprenticeship role. Students are expected to be autonomous intellectuals; dissertations are supposed to be first drafts of books. While graduate students may get systematic feedback from their professors, it is rare that dissertations are in any direct way derivative from the data and projects of their advisers.

In agonizing about the choice of where to be, I stylized the contrast between these two settings by saying that Berkeley was one of the leading intellectual departments in which 1 would be on the discipline oriented wing, whereas Wisconsin was one of the leading discipline oriented departments in which I would be on the intellectual wing. Which of these settings, I thought, do I want to be in? Which would provide the most creative context for my future work? The irony was that although I actually found the intellectual climate of Berkeley more interesting in many ways than that of Wisconsin, I felt that I would be more challenged and pushed in more interesting ways if I was more an intellectual maverick in a disciplinary department than a disciplinary maverick in an intellectualized one. I felt that at this point in history and at this point in my life, perhaps, the creative tension would be more constructive in the Madison department. At Berkeley I would be constantly arguing with the post-structuralist, post-modernist currents about the relevance of culture for everything and the impossibility of explaining anything. In Madison I would be arguing for the importance of an open and dialectical perspective on the relationship between social change and social action and the need for unconventional voices in sociology. So, for better or for worse, I returned to Wisconsin.

\section{Staying a Marxist}

Increasingly in the 1980 's there have been many divorces in the intellectual tradition of Marxism. These divorces have a name now -- post-Marxism. Post-Marxism is very different from earlier ex-Marxisms. In the 1950s, the people who abandoned Marxism often became apologists for the established order. The anti-communist ex-Marxists of those years became enemies of Marxism. Post-Marxism is a very different phenomenon and really shouldn't be viewed in the same way at all. When I became radicalized and first began my intellectual work, Marxism was the only game in town and if you were serious as an intellectual and really wanted to develop theory, in some way or another you had to find a home in or make peace with the Marxist tradition, whether or not you then used the label as a self-designation. That's just not true any longer; there are many currents of radical thought which, to a greater or lesser extent, break with Marxism. Feminism, of course, is the most vibrant of these on the contemporary American scene, but many other kinds of theoretical currents exist as well. Many erstwhile Marxists have thus opted for some variety of post-Marxism. Sometimes this occurs in the form of a declaration in an article or book in which they announce their break; sometimes the shift occurs simply by drifting into a different mode of writing and thinking.

Well, I've remained stubbornly working inside of Marxism and continue to work for the reconstruction rather than abandonment of this intellectual tradition. I do so primarily for the two reasons I described earlier -- that this continues to be a way to remain accountable to a radical intellectual constituency and that in a pluralist environment of models of theoretical work, the eclecticism of others requires the reconstruction of theoretical paradigms.

I have not, however, pursued this goal simply as an individual project of my own. Reconstructing Marxism is not the lonely task of an isolated, ivory-towered intellectual. To sustain these commitments and hope to accomplish these goals requires embedding oneself in a particular set of social networks, a particular circle of people whose work one reads and with whom one discusses issues. A "reference group" is not just an impersonal audience defined by some social category; it is also a circle of people with names and addresses who constitute the active, ongoing basis for the intellectual interactions which spur one's own intellectual development.

In my case, there are two such concrete reference groups that anchor my work. The first "group" consists of a single person, Michael Burawoy, a professor of sociology at Berkeley. Michael and I have read nearly every page that either of us has written in the past fifteen years or so. He is constantly reminding me not to lose sight of the ultimate point of it all by becoming preoccupied with analytical rigor at the expense of political relevance; I am constantly telling him to be more precise in his formulations, to be clearer about the underlying logic of the conceptual distinctions he makes. Our intellectual styles are quite at odds with one another in many ways. He does ethnographic research of an extraordinary fine-grained character; my research 
has been quantitative, typically obliterating much of the nuance and texture of the subjects I study. He is generally skeptical to claims about "objective" truth; I have generally defended rather conventional philosophical views of the scientific aspirations of Marxism and sociology. We have discussed these issues and their bearing on our respective work while walking my dog in the woods and looking for open restaurants in Moscow. (Recently, this dialogue has taken the form of a series of published exchanges between the two of us in the 1987 and 1989 issues of the Berkeley Joumal of Sociology. The first of these exchanges is reprinted in my 1990 book, The Debate on Classes). The particular way in which personal loyalty and closeness is combined with intellectual difference in our relationship has been for me a vital source of intellectual challenge and encouragement. It is also, surely, at least part of the personal dimension of "staying" Marxist.

My deep and abiding relationship with Michael Burawoy acts as a kind of antidote to the second powerful reference group in which I am embedded, a group of scholars that has been at the core of an intellectual current known since the mid-1980's as "Analytical Marxism." The group has a less high-blown name that it gives to itself: the NBSMG -- the No Bullshil Marxism Group. (Actually there was a discussion once in the group as to whether it was non-bullshit or no bullshit, there being a very subtle nuance in the distinction, but I can't reconstruct the philosophical debate.) The NBSMG is a group of scholars from five or six different countries that meets every September in London for a three day conference. Some of the names are relatively familiar -- Jon Elster, Adam Przeworski, G.A. Cohen, John Roemer, Robert Brenner, Sam Bowles -- and a few others may be less so to American sociologists -. Robert van der Veen, Philippe van Parijs, and Hillel Steiner. The group formed in 1979 with no intention of becoming an on-going event. I became a part of it in 1981 and have met with them every year since but one. We meet in the same room every year. We eat the same festive dinner every year. Mostly, we only see each other on this three day period and it's like a little chunk of the year snipped out, reserved for this special world. You have the rest of the year then you have your three day; no bullshit meeting in London.

Here's how the meetings work: Usually of the teri or eleven people who attend a meeting about half will write papers. These get distributed five or six weeks in advance. At the meeting itself, one person is assigned to introduce a given paper; participants do not present their own papers. We spend roughly an hour and a half to two hours demolishing/discussing the paper in a no-holds-barred manner. The group is, as one might predict, all men. The intellectual style is intense and analytically exhausting. To an outsider, many of the discussions might seem destructive, but I think this is a mistake. The interactions involve a particular form of masculine intellectual aggressiveness that is not inherently invalidating; the very act of taking each other's work so seriously is itself an affirmation of respect and support. An outsider wouldn't really see this. If you saw the behavior, you'd think this was a gladiatorial combat in which death was the only possible outcome. But from the inside it is an enormously exciting setting for coming to terms with the subtle problems and gaps in one's ideas and gaining insights about the inner workings of other people's work.

[Digression: We have had discussions in the group from time to time about gender issues, both as a topic -- I presented my paper on Marxism and Feminism at the last meeting -- and as an issue in the group's composition. For better or worse, nobody in the group knew any women scholars who both shared an interest in the substantive topics about which we were concerned and engaged those topics in the intellectual style that marked the group. To be honest, I suppose, many members of the group probably felt that the kind of intensity of the group would also be harder to sustain if it was gender mixed. In any event, no women have been recruited as members of the "club," although several have been invited at various times. In these terms the NBSMG raises important, and troubling, issues in the sociology of gender. Networks of this sort are the real sites where productive intellectual development occurs, where ideas are forged and refined. While the NBSMG does not control any financial resources -- it gives no grants and everyone always pays for their own travel -- nevertheless as a vigorous interpersonal network of intellectual exchange, it is influential and valuable. Undoubtedly the gender composition of the network both reflects the historically marginalized role of women intellectuals in the Marxist tradition and contributes in some way to sustaining such gender inequality.]

Since the early 1980s, the NBSMG is the organized reference group that has mattered most to me. When I write a paper, the ghosts who sit in the back of my room and periodically jump up to tell me that what I have written is ridiculous, and make me worry about whether I got it right, are mainly from this group (or, perhaps, kindred spirits to this group). The group has unquestionably given my work a particular direction and cast because I have to worry, by virtue of this reference group, about certain issues while others seem less pressing.

What are the core ideas of Analytical Marxism? I have written extensively about this elsewhere, so I will only very briefly state the core themes here (The logic of analytical Marxism is discussed at length in my forthcoming book with Andrew Levine and Elliott Sober, Reconstructing Marxism, published by Verso Books). Analytical Marxism is characterized by four principle features:

1. A commitment to conventional scientific noms in the elaboration of theory and the conduct of research. In contrast to much of the Marxist tradition, Analytical Marxists reject the thesis that Marxism has a distinctive methodology and epistemology. Marxism may have distinctive theories about how the world works, but its use of empirical evidence and theoretical argument should be subjected to the same standards as nonMarxist social science. 
Mid-American Review of Sociology

2. An emphasis on the importance of systematic conceptualization, particularly of concepts that are at the core of Marxist theory. This involves both careful attention to definitions of concepts and to the logical coherence of repertoires of interconnected concepts. My longstanding preoccupation with refining the concept of class structure, particularly the "middle class," would be an example of this.

3. A concern with a relatively fine-grained specification of the steps in the theoretical arguments linking concepts, whether the arguments be about causal processes in the construction of explanatory theories or about logical connections in the construction of normative theories. This commitment to elaborating the details of arguments is reflected in one of the hallmarks of Analytical Marxism: the use of explicit, systematic models of the processes being studied. The nature of these models may vary quite a bit, from formal mathematical models to less formal causal models. But in each case there is a belief that the possibility of theoretical advance is enhanced when we are able to generate systematic explicit models of the processes under study.

4. The importance accorded to the study of microfoundations of macrosocial phenomena, frequently through a focus on the intentional action of individuals.

A commitment to these principles does blur the line between Marxism and nonMarxist traditions. This has lead some critics of Analytical Marxism to argue that analytical Marxism is a vehicle for exiting Marxism, not reconstructing it. What, it might be asked, remains Marxist in analytical Marxism? What makes analytical Marxism Marxist is its preoccupation with an agenda of problems embedded in the Marxist tradition, in particular problems that cluster around class analysis, scientific socialism and class emancipation. The questions Analytical Marxists ask are thus anchored in these defining themes of Marxism. The answers they come up with, however, may or may not be characteristically "Marxist" ${ }^{m}$. In the end, the choice of staying Marxist presents itself again and again. Analytical Marxism may generate a sufficient metamorphosis in the nature of the Marxist edifice, that in spite of my decision not to move, I will end up living in a different house.

\section{A PARENT'S VIEW OF A KID GROWING UP IN LAWRENCE}

\author{
Beatrice A. Wright \\ University of Kansas
}

Mid-American Review of Sociology, 1991, Vol. XV, No. 2:15-19

Alan Sica invited me to speak about Erik at this centennial celebration, stating that "your view of how this famous sociologist developed would only augment his own fascinating remarks." Of course I was delighted to do so. I was nonplussed, however, about what to say, and Erik was worried that I would embarrass him. I reassured him by pointing out that, after all, he was a product of the times, the town, his family, including his grandparents who lived in Lawrence at the time, and of course himself; any of his triumphs, therefore, would be triumphs extending to many others as well. In what I have to say, I hope to be able to show that.

To jog my memory of telling events, I proceeded to rummage through files and boxes of treasures and mementoes of the growing-up years of our children. Whenever I came across something noteworthy, I jotted it down. I can assure you that I could talk for hours about what I uncovered. But you need not worry about that, for what follows is but a sample of a variety of things that went into the emergence of Erik as Erik.

One of the main reasons we decided to join the University was because we felt that Lawrence would be a good place to rear children. From the start Erik found himself in a world of wonderful happenings. He attended the KU nursery school, so full of things to build and do with other children. I remember how pleased parents were to have him in their carpool because the children, instead of poking at each other, would be held in rapt attention by his fanciful stories. He still is a great story teller, and I believe that the delight of the preschoolers then is part of his own delight to this very day when making up silly and adventuresome stories to a group of children who clamor for more.

I recall that when Erik was in the first grade, he recounted that his teacher had said there were three glasses in a quart and he said, no, there were four. He was troubled about the disagreement. We reassured him that there were four glasses in a quart. When he returned from school the next day, he had a tale to tell. He told us that when he again said that there were four glasses in a quart, his teacher poured three glasses into a quart container, and showed him that there was no more room for a fourth. Perplexed he was. We then explained the notion of standard-sized glasses, which he promptly passed on to his teacher, who replied that she used tumblers and let the issue go at that. I mention this incident to show that the teacher did not squelch him, but rather allowed his own searching for answers. I believe that this was true for most of his school experiences.

The local newspaper, the Lawrence Journal World, did much to let the children know that they were important. Here are two news photos, one showing Erik with other children listening to a fairy tale at the city library's 